DOI: https://doi.org/10.47405/mjssh.v7i1.1252

\begin{tabular}{|c|c|}
\hline 4 & Malaysian Journal of Social Sciences and Humanities (MJSSH) \\
\hline $\begin{array}{l}\text { Malaysian Journal of } \\
\text { Social sciences and }\end{array}$ & Volume 7, Issue 1, January 2022 \\
\hline (MJ-sSH) & e-ISSN : 2504-8562 \\
\hline & $\begin{array}{l}\text { Journal home page: } \\
\text { www.msocialsciences.com }\end{array}$ \\
\hline
\end{tabular}

\title{
Kesediaan Guru Pendidikan Khas Pembelajaran dalam Pelaksanaan Pengajaran Abad Ke-21 (PAK-21)
}

\author{
Nurhibbah binti Majid1, Rosadah binti Abdul Majid1 \\ 1Fakulti Pendidikan, Universiti Kebangsaan Malaysia (UKM), Malaysia \\ Correspondence: Nurhibbah binti Majid (majidnurhibbah@gmail.com)
}

\begin{abstract}
Abstrak
Pembelajaran abad ke-21 (PAK 21) merujuk kepada inisiatif Kementerian Pendidikan untuk meningkatkan kualiti sistem pendidikan melalui keberhasilan murid melalui lima elemen standard pengajaran PAK 21. Objektif kajian dijalankan untuk mengkaji tahap kesediaan guru khas masalah pembelajaran dari segi pengetahuan, kemahiran dan hubungan antara pengetahuan dan kemahiran dalam melaksanakan pembelajaran abad ke-21 (PAK 21) semasa proses pengajaran dan pembelajaran dijalankan. Data diperolehi melalui rekabentuk kaedah tinjauan atas talian yang melibatkan 60 orang guru pendidikan khas masalah pembelajaran sekitar daerah Johor Bahru. Instrumen kajian menggunakan soal selidik skala Likert 4 mata dan hasil kajian dianalisa dengan menggunakan program Statisttical Packages for Social Science (SPSS). Dapatan kajian menunjukkan bahawa tahap pelaksanaan PAK 21 di kalangan guru-guru khas masalah pembelajaran dari segi pengetahuan dan kemahiran adalah di tahap sederhana $(\mathrm{min}=2.92)$. Namun demikian, terdapat hubungan yang kuat antara pengetahuan dan kemahiran dalam melaksanakan PAK 21. Hasil kajian memberi implikasi terhadap keperluan dan latihan guru pada masa akan datang dalam menyediakan guru-guru pendidikan khas masalah pembelajaran yang berkemahiran dalam PAK 21.
\end{abstract}

Kata kunci: Pembelajaran Abad ke-21, tahap kesediaan, pengetahuan, kemahiran

\section{Preparedness Of Special Education Teachers for Learning in The Implementation of 21st Century Teaching}

\begin{abstract}
The purposes of this study are examine the level of readiness of special teachers of learning disabilities in term of knowledge, skills and the relationship between knowledge and skills in implementing 21 st century learning (PAK 21) during the teaching and learning process. Data are obtain through an online survey method involving 60 special education teachers araound the district of Johor Bahru. The research instrument use a questionnaire using a 4-point Likert Scale and the results were analyze descriptively and inferentially,by using Statistical Packages for Social Sciences (SPSS) software. The findings of the study showed that the level of implementation of 21st Century Learning among special teachers of learning difficulties in terms of knowledge and skills is at a moderate level (mean $=2.92$ ). Nevertheless, it was found that there is a strong relationship between knowledge and skills in implementing PAK 21. The results of the study have implications for the needs and training of teachers in the future in providing special education teachers with learning difficulties skilled in 21 st Century Learning.
\end{abstract}


Keywords: 21st Century Learning, level of readiness, knowledge, skills

\section{Pengenalan}

Di abad ke-21, perkembangan dunia semasa menjadi semakin mencabar. Dalam tempoh yang dinamik ini, permintaan terhadap pembangunan teknologi dan komunikasi memerlukan penambahbaikan dalam pengajaran dan pembelajaran di sekolah. Selaras dengan itu, Kementerian Pendidikan Malaysia telah melaksanakan Pembelajaran Abad ke-21 (PAK 21) untuk mengangkat taraf pendidikan negara selaras dengan negara maju yang lain. Pendidikan berkualiti dan cemerlang dalam pelbagai aspek adalah menjadi matlamat utama KPM bagi melahirkan generasi abad ke-21 yang berilmu pengetahuan dan berkemahiran. Kesinambungan dengan itu, KPM telah menggariskan dalam Pelan Induk Pembangunan Pendidikan (PIPP) 2006 - 2010 (KPM, 2006) dan gagasan Pelan Pembangunan Pendidikan Malaysia (PPPM) 2013-2025 (KPM, 2013) dengan menekankan konstruk kemahiran abad ke-21 yang sewajarnya dalam proses pengajaran dan pembelajaran di dalam kelas. Atas kesedaran itu, guru-guru perlu memyediakan diri dengan ilmu pengetahuan dan kemahiran PAK 21 untuk memenuhi tanggung jawab bagi melaksanakan pengajaran yang berkesan. Oleh itu, kesediaan guru sangat diperlukan dalam melaksanakan pengajaran dan pembelajaran PAK 21 dengan mengintegrasikan kemahiran komponen abad ke-21 iaitu proses pembelajaran yang mengandungi elemen komunikasi, kolaboratif, kritis, kreatif dan mengaplikasikan nilai murni serta etika.

Kementerian Pendidikan Malaysia (KPM, 1996) menyatakan murid berkeperluan khas (MBK) adalah individu yang disahkan oleh ahli perubatan dalam bidang berkaitan yang mengalami ketidakupayaan penuh atau sebahagian dalam penglihatan, pendengaran, pertuturan, ketidakupayaan fizikal dan juga masalah pembelajaran. Secara amnya, mereka perlu mendapat bimbingan sebagai individu yang mempunyai kemahiran,berdikari dalam hidup dan mampu menguruskan hidup sendiri. Hassan et.al (2006)menyatakan bahawa MBK memerlukan perhatian dan galakan serta boleh menyumbang kepada negara kerana mereka juga merupakan sebahagian daripada sumber tenaga yang dijana untuk mencapai kemajuan negara. Tambahan dalam program pendidikan khas dimana MBK ini ditempatkan, pendekatan yang lebih strategik, keperluan bantuan khas, sokongan dan rancangan pengajaran yang bersesuaian diberikan dengan keperluan dan potensi mereka. Dengan itu, murid berkeperluan khas (MBK) ini memerlukan para guru yang berkemahiran dan kompeten dalam pengajaran serta mendidik selari dengan PAK 21 agar dapat melahirkan modal insan yang sejahtera seiring dengan perkembangan zaman.

Sehubungan dengan itu, kajian ini mempunyai obejektif seperti di bawah :

i. Mengenal pasti tahap kesediaan guru khas masalah pembelajaran daripada aspek pengetahuan dalam melaksanakan PAK 21

ii. Mengenal pasti tahap kesediaan guru khas masalah pembelajaran daripada aspek kemahiran dalam pelaksanaan PAK 21.

iii. Mengenalpasti adakah terdapat hubungan antara pengetahuan dengan kemahiran dalam pelaksanaan PAK 21.

\section{Sorotan Literatur}

\section{Pengajaran Abad Ke-21 (PAK 21)}

Pengajaran yang berpusatkan murid dan berteraskan lima standard asas atau kemahiran iaitu kemahiran kreativiti (creativity), komunikasi (communication), kolaborasi (collaboration) dan pemikiran kritikal (critical thinking) serta mengamalkan nilai dan etika yang telah dilaksanakan oleh Kementerian Pendidikan Malaysia (KPM) pada tahun 2014 dan meluaskan pelaksanaannya ke seluruh negara pada tahun 2015 menerusi KSSR dan KSSM. Kumar (2016) juga menyatakan bahawa PAK 21 bukan sahaja dikaitkan dengan perkembangan teknologi dalam pengajaran, namun PAK 21 adalah penggunaan 
teknologi yang optimum dalam pembelajaran dapat memberikan impak yang positif dan besar pada diri murid.

\section{Kesediaan Guru}

Thorndike dalam Mok (2004) menyatakan Hukum Kesediaan terbahagi kepada:

i. Apabila seseorang bersedia melakukan sesuatu tindakan dan berjaya melaksanakannya, hasil usaha itu akan memberi sesuatu kepuasan kepada dirinya.

ii. Apabila seseorang itu bersedia melakukan sesuatu tindakan, namun demikian tindakan itu tidak dapat dilaksanakan, hasil daripada itu individu tersebut akan kecewa.

iii. Seseorang itu dipaksa untuk melakukan sesuatu, namun belum bersedia, hasil tindakan itu juga akan menimbulkan perasaan kecewa dan tertekan.

Raziyah (2008) menyatakan kesediaan guru dalam pelaksanaan pengajaran perlu kepada empat aspek iaitu ilmu pengetahuan, emosi, rohani dan jasmani dan penerimaan tanggung jawab guru terutama guru pendidikan khas dalam membentuk murid berjaya dalam hidup. Namun dalam konteks kajian ini bertujuan melihat kepada kesediaan guru dari aspek iaitu ilmu pengetahuan, kemahiran dan hubungan keduanya dalam melaksanakan pengajaran PAK 21 untuk murid berkeperluan khas (MBK) masalah pembelajaran.

Untuk persediaan pelaksanaan PAK 21, guru merupakan sumber utama untuk membawa perubahan. Pengetahuan pedagogi dalam kemahiran PAK 21 merupakan peranan penting dalam mengimplementasikan PAK 21 di dalam bilik darjah. Rusdin (2018) menyatakan dalam kajian nya, bahawa guru bersedia untuk melaksanakan PAK 21, namun mereka mempunyai pengetahuan dan kemahiran yang sederhana mengenai konsep PAK 21 untuk melaksanakannya dalam pengajaran di dalam kelas.

Menurut Raja Maznah (2008) kesediaan guru merupakan persediaan dan keyakinan untuk guru itu melaksanakan pengajaran. Kesediaan guru melibatkan aspek fizikal, mental dan spiritual (Raja Maznah 2008 \& Hamidah 2002) iaitu merujuk kepada kemahiran guru pengajaran di dalam kelas manakala aspek mental merujuk kepada guru bersedia dari ilmu pengetahuan dalam melaksanakan pengajaran manakala aspek spiritual merujuk kepada sikap guru dalam melaksanakan pengajaran dan pembelajaran. Komponen 4C perlu ada pada kesediaan guru dalam melaksanakan pengajaran berlandaskan PAK 21. Oleh yang demikian, guru perlu melengkapkan diri supaya pengajaran guru lebih berkesan. Pernyataan ini disokong oleh Abdul Rahman (2005) bahawa kesediaan guru yang tinggi merupakan bukti bahawa guru tersebut melaksanakan tanggungjawabnya dengan baik dan cemerlang

\section{Kesediaan Guru Dari Aspek Pengetahuan}

Zarina Abdul Rashid (2016) menyatakan pengetahuan adalah menjelaskan sesuatu pemahaman atau konsep ke atas sesuatu subjek dan menggunakannya untuk tujuan sesuatu. Melalui tafsiran National Council for Accreditation of Teacher Education (2008) menyatakan pengetahuan adalah penguasaan ilmu yang dimiliki oleh guru meliputi prinsip dan konsep. Penulisan yang sama juga dinyatakan oleh Izlin (2002) menyatakan pengetahuan yang dimiliki oleh guru meliputi pedagogi, isi pengetahuan, pengetahuan am dan pengetahuan ikhtisas perguruan. Menurut Fatimah et al. (2006) sumber pengetahuan di abad 21 ini adalah berkaitan dengan teknologi dan maklumat (ICT). Perkara yang sama juga diutarakan oleh Mary Yap (2015) guru perlu melengkapkan diri dengan ilmu pengetahuan mengenai teknologi pedagogi yang secara menyeluruh, meneroka pengajaran pelbagai mod yang bertemakan teknologi dan mempunyai pemikiran yang kritis dan kreatif dalam melaksanakan pengajaran PAK 21.

\section{Kesediaan Guru Dari Aspek Kemahiran}

Nurulhuda (2015) menyatakan kemahiran merupakan satu seni, kebolehan atau kaedah yang diperolehi melalui pengalaman yang memerlukan penggunaan anggota badan. Nurzarina dan Rosli (2017) 
menyatakan bahawa guru perlu melengkapkan diri dengan kemahiran 21 seperti berkolaborasi serta kemahiran yang lain dengan memahami pelaksanaan pengajaran PAK 21 dan bagaimana guru menekankan kemahiran tersebut dibina dalam diri murid. Wan Azlin dan rakan-rakan (2017) juga menegaskan guru abad ke-21 perlu menguasai pedagogi abad ke-21, pembangunan murid dan bantuan terhadap mereka, kemahiran psikologi dan kemahiran kaunseling juga diperlukan. Perkara yang sama juga diutarakan oleh Faridah Nazir et al. (2016) menyatakan guru perlu mempunyai kemahiran penggunaan ICT, berketerampilan dalam pedagogi dan penyampaian yang berkesan agar boleh diterima oleh murid serta boleh mengaplikasikan teknologi seperti Program SLE (Smart Learning Environment).

\section{Metod Kajian}

\section{Rekabentuk Kajian}

Kajian ini menggunakan reka bentuk kajian tinjauan dan data yang dikumpul berbentuk kuantitatif yang menggunakan soal selidik melalui atas talian. Kaedah tinjauan dipilih kerana ia mudah, efisien dan cepat dalam memperoleh maklumat dalam sesebuah populasi. Soal selidik yang kajian ini diadaptasi daripada kajian Rahmat (2014). Item soalan disesuaikan dengan tajuk kajian bagi memastikan item-item yang dalam soal selidik adalah berkaitan dengan PAK 21 dan juga disesuaikan dalam bidang pendidikan khas masalah pembelajaran. Soal selidik terbahagi kepada tiga bahagian iaitu Bahagian A ialah profil responden, Bahagian B adalah soal selidik berkaitan dengan tahap kesediaan pengetahuan manakala Bahagian $\mathrm{C}$ adalah berkaitan dengan tahap kesediaan kemahiran guru.

\section{Populasi dan persampelan}

Populasi kajian terdiri daripada guru-guru pendidikan khas di 12 buah sekolah menengah pendidikan khas integrasi di daerah Johor Bahru. Daripada populasi kajian tersebut, 60 orang guru dipilih sebagai sampel kajian berdasarkan formula Krejcie dan Morgan (1970). Pemilihan sampel dibuat menggunakan sampel rawak mudah. Guru yang dipilih akan menjawab konstruk terhadap aspek pelaksanaan PAK 21 di sekolah-sekolah tersebut kerana tempoh perkhidmatan yang melebihi lima tahun.

Kajian rintis telah dilaksanakan dalam terhadap 25 orang guru pendidikan khas yang berada di dalam populasi kajian. Guru-guru ini adalah bukan sampel sebenar bagu menjawab kajian. Mohd Majid Konting (2000) menyatakan sebelum melakukan kajian yang sebenar, kajian rintis perlu dilaksanakan untuk menguji sampel dari populasi yang sama yang dikaji untuk mendapatkan kebolehpercayaan itemitem soal selidik. Hasil dapatan data diperolehi nilai pekali kebolehpercayaan Alpha Cronbach keseluruhan item adalah 0.958. Alpha Cronbach mestilah sekurang-kurangnya 0.700 untuk menilai kebolehpercayaan instrumen menurut Johnson \& Christensen ( 2008).

\section{Kaedah Pengumpulan Data}

Penganalisaan data untuk kajian ini dilakukan dengan menggunakan Statistical Packages of the Science version 22.0 (Window SPSS version 22.0). Berikut ialah ujian yang dilakukan bagi menjawab soalan kajian:

i. Apakah tahap kesediaan guru khas masalah pembelajaran dari aspek pengetahuan dalam melaksanakan PAK21 di sekolah? ( Min )

ii. Apakah tahap kemahiran guru khas masalah pembelajaran dalam dalam pelaksanaan PAK 21?

iii. (Min)

iv. Adakah terdapat hubungan yang signifikan antara pengetahuan dengan kemahiran dalam melaksanakan PAK 21 ? ( Ujian Korelasi Pearson)

\section{Instrumen Kajian}

Google Form merupakan instrumen yang digunakan dalam kajian ini. Responden dikehendaki untuk memilih jawapan yang berbentuk Skala Likert 4 mata pemeringkatan dengan menanda jawapan mereka mengikut skala dan responden membuat pemilihan jawapan mengikut tahap persetujuan mereka. Tahap 
persetujuan mengandungi empat tahap iaitu Sangat Tidak Setuju (STS) Tidak Setuju (TS), Setuju (S) dan Setuju Sangat (SS).

\section{Hasil Kajian}

Data yang diperolehi daripada kajian yang dijalankan dianalisis dan dihuraikan dalam dua bahagian iaitu profil demografi responden dan analisis persoalan kajian. Hasil analisis dapatan adalah seperti jadual di bawah.

\section{Profil Demografi}

Kajian ini melibatkan 60 orang guru pendidikan khas program integrasi sekolah menengah. Daripada jumlah itu, seramai 12 orang ( $20 \%$ ) ialah guru lelaki dan 48 orang ( $80 \%$ ) orang responden adalah perempuan. Bagi faktor umur di dapati 3 orang responden ( $5.0 \%$ ) berumur 20-30 tahun, 34 responden ( $56.7 \%$ ) berusia $31-40$ tahun, 16 responden ( $26.7 \%$ ) berumur 41 tahun hingga 50 tahun manakala hanya 7 responden $(11.7 \%)$ berusia 51 tahun ke atas.

Jadual 1: Demografi Responden

\begin{tabular}{|c|c|c|c|}
\hline Bil & Maklumat & Kekerapan & Peratus ( \%) \\
\hline \multirow[t]{3}{*}{1} & Gender & & \\
\hline & Lelaki & 12 & 20 \\
\hline & Perempuan & 48 & 80 \\
\hline \multirow[t]{5}{*}{2} & Umur & & \\
\hline & 20-30 tahun & 3 & 5.0 \\
\hline & 31- 40 tahun & 34 & 56.7 \\
\hline & $41-50$ tahun & 16 & 26.7 \\
\hline & 51 tahun ke atas & 7 & 11.7 \\
\hline \multirow[t]{5}{*}{3} & Bangsa & & \\
\hline & Melayu & 58 & 96.7 \\
\hline & Cina & 0 & 0 \\
\hline & India & 1 & 1.7 \\
\hline & Lain-lain & 1 & 1.7 \\
\hline \multirow[t]{4}{*}{4} & Jawatan & & \\
\hline & PK Pendidikan Khas & 0 & 0 \\
\hline & Penyelaras Pendidikan Khas & 17 & 28.3 \\
\hline & Guru Pendidikan Khas & 43 & 71.7 \\
\hline \multirow[t]{3}{*}{5} & Pengkhususan & & \\
\hline & Pendidikan Khas & 48 & 80 \\
\hline & Lain-lain & 12 & 20 \\
\hline \multirow[t]{5}{*}{6} & Kelayakan Akademik & & \\
\hline & Sarjana & 0 & 0 \\
\hline & Sarjana Muda & 59 & 98.3 \\
\hline & Diploma & 0 & 0 \\
\hline & Sijil & 1 & 1.7 \\
\hline \multirow[t]{6}{*}{7} & Tempoh Berkhidmat & & \\
\hline & $1-5$ tahun & 5 & 8.3 \\
\hline & 6-10 tahun & 11 & 18.3 \\
\hline & $11-15$ tahun & 29 & 48.4 \\
\hline & 16- 20 tahun & 3 & 5.0 \\
\hline & 20 tahun keatas & 12 & 20.0 \\
\hline \multirow[t]{4}{*}{8} & Pengalaman Mengajar di PPKI & & \\
\hline & $1-5$ tahun & 7 & 11.7 \\
\hline & $6-10$ tahun & 10 & 16.7 \\
\hline & 11-15 tahun & 31 & 51.7 \\
\hline
\end{tabular}



DOI: https://doi.org/10.47405/mjssh.v7i1.1252

$\begin{array}{lll}16-20 \text { tahun } & 5 & 8.3 \\ 20 \text { tahun keatas } & 7 & 11.7\end{array}$

Bagi demografi untuk bangsa, sebanyak 58 orang responden berbangsa Melayu dan India dan Lain-lain masing-masing mewakili 1 responden sahaja ( 1.7\%) Bagi maklumat jawatan yang dipegang di sekolah, seramai 17 orang responden ( $28.3 \%$ ) terdiri daripada penyelaras pendidikan khas dan 43 responden ( $71.1 \%$ ) terdiri daripada guru-guru pendidikan khas.

Bagi maklumat bidang pengkhususan responden didapati 48 orang responden ( $80 \%$ ) merupakan opsyen pendidikan khas manakala yang selebihnya iaitu 12 orang responden (20\%) merupakan pengkhususan yang lain-lain seperti Geografi, Bahasa Melayu, Ekonomi dan Matematik. Bagi faktor kelayakan akademik, sebanyak 59 orang responden (98.3\%) mempunyai Sarjana Muda Pendidikan dan 1 orang responden mengambil sijil ( DPLI)

Untuk elemen tempoh perkhidmatan responden sebagai guru didapati seramai 5 orang responden (8.3 $\%)$ berkhidmat di antara 1-5 tahun, 11 responden (18.3\%) berkhidmat 6-10 tahun, sebahagian besar responden (48.4\%) adalah yang berkhidmat 11-15 tahun, 3 responden ( $5.0 \%$ ) berkhidmat 16-20 tahun manakala sebanyak 12 responden (20\%) telah berkhidmat selama 20 tahun ke atas. Manakala untuk maklumat tempoh pengalaman mengajar di PPKI, seramai 7 orang $(11.7 \%)$ responden berpengalaman 1-5 tahun, 10 orang $(16.7 \%)$ responden mempunyai pengalaman 6-10 tahun, 31 orang responden (51.7\%) berpengalaman mengajar antara 11-15 tahun, 5 orang respnden $(8.3 \%)$ berpengalaman 16-20 tahun dan 7 orang responden ( $11.7 \%$ ) mempunyai pengalaman 20 tahun ke atas.

\section{Mengenalpasti tahap kesediaan guru khas masalah pembelajaran daripada aspek pengetahuan dalam pelaksanaan PAK 21}

Rumusan dapatan bagi konstruk (1) iaitu kesediaan guru daripada aspek pengetahuan mendapati setiap 10 soalan yang dikaji di tahap sederhana. Item min yang paling tinggi ialah pada soalan B8 ( $\mathrm{M}=3.10)$ iaitu "saya tahu bagaimana menyampaikan pengajaran berbentuk visual kepada murid dengan menggunakan teknologi". Item pengajaran B4 $(\mathrm{M}=2.92)$, "saya tahu menjalankan amali berasaskan PAK 21" dan B5 ( $\mathrm{M}=2.92)$ iaitu "dengan mengaitkan keadaan kehidupan pelajar, saya tahu mengembangkan pemikiran kritis" mempunyai min yang sama manakala item yang mempunyai min rendah ialah B6 $(\mathrm{M}=2.55)$ iaitu "dalam proses penghasilan idea, saya tahu cara mengendalikan PAK 21 menggunakan pendekatan STEM". Dapatan kajian secara keseluruhan bagi item konstruk pengetahuan guru dalam pelaksanaan PAK 21 adalah di tahap sederhana.

Jadual 2: Konstruk 1

\begin{tabular}{llllllll}
\hline Bil & Perkara & & & \multicolumn{5}{c}{ Kekerapan/Peratus } \\
\hline & & STS & TS & S & SS & Min & Tahap \\
\hline B1 & $\begin{array}{l}\text { Saya tahu untuk mengaplikasikan } \\
\text { teknik penyoalan KBAT dalam }\end{array}$ & 0 & 2 & 51 & 7 & 3.08 & Sederhana \\
pengajaran. & 0 & 3.3 & 85 & 11.7 & & \\
B2 & $\begin{array}{l}\text { Saya boleh mengendalikan pelbagai } \\
\text { aktiviti PAK 21 seperti Think-Pair- }\end{array}$ & 0 & 15 & 42 & 3 & 2.80 & Sederhana \\
& $\begin{array}{l}\text { Share, Hot Seat, Gallery Walk dan } \\
\text { Round Table. }\end{array}$ & 0 & 25.0 & 70.0 & 5.0 & & \\
Dalam PdPc saya biasa & & & & & & \\
mengendalikan pembelajaran & 0 & 9 & 42 & 9 & 3.00 & Sederhana \\
& $\begin{array}{l}\text { kolaboratif seperti bekerjasama } \\
\text { untuk menyelesaikan tugasan }\end{array}$ & 0 & 15.0 & 70.0 & 15.0 & & \\
dengan baik & & & & & & \\
Saya faham menjalankan Pdpc & & & & & & Sederhana \\
amali berasaskan PAK 21. & 0 & 12 & 41 & 7 & 2.92 \\
\end{tabular}


B5 Dengan mengaitkan keadaan

kehidupan pelajar, saya tahu

mengembangkan pemikiran kritis

$\begin{array}{llllll}0 & 12 & 41 & 7 & 2.92 & \text { Sederhana } \\ 0 & 20.0 & 68.3 & 11.7 & & \end{array}$

B6 Dalam proses penghasilan idea

dalam pengajaran saya tahu cara

mengendalikan PAK 21

$\begin{array}{llllll}0 & 30 & 27 & 3 & 2.55 & \text { Sederhana }\end{array}$

menggunakan pendekatan STEM

B7 Saya boleh mentaksir kebolehan murid ketika melaksanakan aktiviti PAK 21.

$\begin{array}{llll}0 & 50.0 & 45.0 & 5.0\end{array}$

B8 Saya tahu bagaimana

menyampaikan pengajaran

berbentuk visual kepada murid

dengan menggunakan teknologi.

B9 Dengan melibatkan pelajar dengan

pelbagai pandangan mereka saya

tahu mengatur proses PAK 21

dengan baik.

$\begin{array}{llllll}0 & 10 & 44 & 6 & 2.93 & \text { Sederhana } \\ 0 & 16.7 & 73.3 & 10.0 & & \end{array}$

B1 Saya memahami cara \begin{tabular}{llllllll}
0 & mengintegrasikan penilaian bilik & 0 & 4 & 49 & 7 & 3.05 & Sederhana \\
darjah melalui hasil pengajaran. & 0 & 6.6 & 81.7 & 11.7 & & \\
\hline
\end{tabular}

Jumlah Keseluruhan (n) $=60$

Min Keseluruhan 2.92

\section{Mengenalpasti tahap kesediaan guru khas masalah pembelajaran daripada aspek kemahiran dalam pelaksanaak PAK 21}

Bagi dapatan kajian konstruk (2) iaitu bagi menjawab persoalan kajian yang ke-2, apakah tahap kesediaan guru daripada aspek kemahiran, terdapat 12 item yang diberikan untuk di jawab oleh responden. Item soalan yang mempunyai min tinggi ialah $\mathrm{C} 9(\mathrm{M}=3.17)$ 'saya mahir memujuk murid berkomunikasi semasa murid melaksanakan projek'. Item untuk $\mathrm{C} 4(\mathrm{M}=3.03)$ 'dalam PAK 21, saya mahir dalam melaksanakan carta insentif untuk respon dan tingkahlaku yang baik' adalah pada min yang sederhana manakala item soalan min yang paling rendah adalah pada soalan $C 6(M=2.87)$, 'saya berkemahiran dalam mencipta pentaksiran berasaskan PAK 21 yang relevan mengikut kemajuan pelajar. Secara keseluruhannya kajian mendapati item kesediaan guru daripada aspek kemahiran adalah pada tahap sederhana.

Jadual 2: Kontruk 2

\begin{tabular}{llllllll}
\hline \multirow{2}{*}{ Bil } & Perkara & \multicolumn{7}{c}{ Kekerapan/Peratus } \\
\cline { 2 - 7 } & STS & TS & S & SS & Min & Tahap \\
\hline C1 & $\begin{array}{l}\text { Saya tahu menggunakan } \\
\text { strategi penyoalan bilik } \\
\text { darjah untuk }\end{array}$ & 0 & 5 & 44 & 11 & 3.10 & Sederhana \\
menggalakkan interaksi & 0 & 8.3 & 73.3 & 18.4 & & \\
C2 & & & & & & & \\
guru-murid & $\begin{array}{l}\text { Berdasarkan PAK 21 saya } \\
\text { boleh mentadbir isi atau } \\
\text { skop pembelajaran } \\
\text { mengikut kemampuan } \\
\text { murid menggunakan }\end{array}$ & 0 & 6 & 45 & 9 & 3.05 & Sederhana \\
kaedah dan teknik (PKT) & & 10.0 & 75.0 & 15.0 & & \\
yang betul & & & & & & & \\
Saya mahir mengadaptasi & & & & & & \\
\hline
\end{tabular}



DOI: https://doi.org/10.47405/mjssh.v7i1.1252

\begin{tabular}{|c|c|c|c|c|c|c|c|}
\hline & latihan dan PAK 21 sesuai & 0 & 7 & 46 & 7 & 3.00 & Sederhana \\
\hline & $\begin{array}{l}\text { dengan topik dan objektif } \\
\text { pembentangan. }\end{array}$ & 0 & 11.7 & 76.7 & 11.7 & & \\
\hline \multirow[t]{2}{*}{$\mathrm{C} 4$} & $\begin{array}{l}\text { Dalam aktiviti PAK 21, } \\
\text { saya mahir dalam }\end{array}$ & 0 & 10 & 38 & 12 & 3.03 & Sederhana \\
\hline & $\begin{array}{l}\text { melaksanakan carta } \\
\text { insentif untuk respon dan } \\
\text { juga tingkahlaku yang baik }\end{array}$ & 0 & 16.7 & 63.3 & 20.0 & & \\
\hline \multirow[t]{2}{*}{ C5 } & $\begin{array}{l}\text { Saya cemerlang dalam } \\
\text { menggunakan kaedah }\end{array}$ & 0 & 9 & 44 & 7 & 2.97 & Sederhana \\
\hline & $\begin{array}{l}\text { pengajaran dan } \\
\text { pembelajaran kolaboratif }\end{array}$ & 0 & 15.0 & 73.3 & 11.7 & & \\
\hline \multirow[t]{2}{*}{ C6 } & $\begin{array}{l}\text { Saya berkemahiran dalam } \\
\text { mencipta pentaksiran }\end{array}$ & 0 & 13 & 42 & 5 & 2.87 & Sederhana \\
\hline & $\begin{array}{l}\text { berasaskan PAK } 21 \text { yang } \\
\text { relevan mengikut } \\
\text { kemajuan pelajar. }\end{array}$ & 0 & 21.7 & 70.0 & 8.3 & & \\
\hline \multirow[t]{2}{*}{ C7 } & $\begin{array}{l}\text { Saya mahir dalam } \\
\text { menggunakan komputer }\end{array}$ & 0 & 10 & 42 & 8 & 2.97 & Sederhana \\
\hline & $\begin{array}{l}\text { dalam mencipta bahan } \\
\text { pengajaran PAK } 21 .\end{array}$ & 0 & 16.7 & 70.0 & 13.3 & & \\
\hline \multirow[t]{2}{*}{$\mathrm{C} 8$} & $\begin{array}{l}\text { Saya mampu mengumpul } \\
\text { maklumat tentang }\end{array}$ & 0 & 6 & 44 & 13 & 3.07 & Sederhana \\
\hline & $\begin{array}{l}\text { prosedur atau pendekatan } \\
\text { PAK21 unruk } \\
\text { meningkatkan kefahaman } \\
\text { mengenai pelaksanaan } \\
\text { PAK } 21 .\end{array}$ & 0 & 10.0 & 73.3 & 21.7 & & \\
\hline \multirow[t]{2}{*}{ C9 } & $\begin{array}{l}\text { Saya mahir memujuk } \\
\text { murid berkomunikasi }\end{array}$ & 0 & 3 & 44 & 13 & 3.17 & Sederhana \\
\hline & $\begin{array}{l}\text { semasa murid } \\
\text { melaksanakan projek. }\end{array}$ & 0 & 5.0 & 73.3 & 21.7 & & \\
\hline \multirow[t]{2}{*}{$\mathrm{C} 10$} & $\begin{array}{l}\text { Saya mahir menyelaras } \\
\text { operasi PAK } 21 \text { mengikut }\end{array}$ & 0 & 7 & 47 & 6 & 2.98 & Sederhana \\
\hline & jadual. & 0 & 11.7 & 78.3 & 10.0 & & \\
\hline \multirow[t]{3}{*}{ C11 } & Mengwal aktiviti PAK & & & & & & \\
\hline & 21dalam proses & 0 & 9 & 43 & 8 & 2.98 & Sederhana \\
\hline & $\begin{array}{l}\text { pengajaran merupakan } \\
\text { kemahirang yang ada pada } \\
\text { diri saya. }\end{array}$ & 0 & 15.0 & 71.7 & 13.3 & & \\
\hline \multirow[t]{3}{*}{$\mathrm{C} 12$} & $\begin{array}{l}\text { Saya berkemahiran } \\
\text { menyertai aktiviti yang }\end{array}$ & 0 & 8 & 44 & 8 & 3.00 & Sederhana \\
\hline & $\begin{array}{l}\text { mementingkan } \\
\text { pertandingan } \\
\text { berkumpulan. }\end{array}$ & 0 & 13.3 & 73.3 & 13.3 & & \\
\hline & $\begin{array}{l}\text { Jumlah Keseluruhan }(n)= \\
\text { Min Keseluruhan 3.02 }\end{array}$ & & & & & & \\
\hline
\end{tabular}

\section{Mengenalpasti adakah terdapat hubungan antara pengetahuan dan kemahiran dalam pelaksanaan PAK 21}

Dapatan kajian digunakan untuk menjawab persoalan yang ketiga. Kajian mendapati bahawa pekali Korelasi Pearson antara pengetahuan dan kemahiran dalam melaksanakan PAK-21 guru-guru pendidikan khas di daerah Johor Bahru adalah $r=0.76, P=0.00(p<0.05)$. Ini menunjukkan bahawa kedua 
pemboleh ubah berhubung secara positif dengan kekuatan hubungan di tahap yang kuat iaitu $\mathrm{r}=0.76$ berdasarkan interpretasi pekali korelasi oleh Jackson ( 2012).

Jadual 3: Hubungan antara pengetahuan dan kemahiran

\begin{tabular}{llll}
\hline & & Pengetahuan & Kemahiran \\
\hline Pengetahuan & Pearson Correlation & 1 & $.764^{* *}$ \\
& Sig. (2-tailed) & 60 & .000 \\
Kemahiran & N & $.764^{* *}$ & 60 \\
& Pearson Correlation & .000 & 1 \\
Sig. (2-tailed) & 60 & 60 \\
**. Correlation is significant at the 0.01 level (2-tailed). & \\
\hline
\end{tabular}

Jadual 4: Kekuatan Hubungan

\begin{tabular}{ll}
\hline Skala Pekali Korelasi & Kekuatan Hubungan \\
\hline \pm 0.01 hingga \pm 0.29 & Tiada hubungan hingga lemah \\
\pm 0.30 hingga \pm 0.69 & Sederhana \\
\pm 0.70 hingga \pm 1.00 & Kuat \\
\hline
\end{tabular}

\section{Perbincangan}

Dapatan kajian ke atas guru-guru pendidikan khas daerah Johor Bahru menunjukkan min keseluruhan ialah 2.92 adalah pada tahap sederhana, ini menunjukkan guru pendidikan khas mempunyai tahap kompetensi yang sederhana dalam melaksanakan pengajaran dan pembelajaran (PAK 21). Ini selari dengan kajian Rusdin (2018) menyatakan bahawa guru bersedia untuk melaksanakan PAK 21, namun mereka mempunyai pengetahuan dan kemahiran yang sederhana mengenai konsep PAK 21. Kesediaan guru juga dikatkan dengan ciri demografi iatu tempoh pengalaman. Berdasarkan hasil dapatan, program latihan atau kursus PAK 21 wajar dilaksanakan memandangkan pengajaran PAK 21 ini masih baru diperkenalkan. Seminar dan bengkel sebagai contoh, perlu diadakan secara berkala untuk menangani keperluan individu guru pada peringkat kerjaya yang berbeza.

Selain itu, guru pendidikan khas menyedari kepentingan untuk mengaplikasi strategi pengajaran berbentuk visual berbantukan teknologi di kalangan murid-murid pendidikan khas masalah pembelajaran. Dapatan ini menyokong kajian Fatimah et al. (2006) yang menyatakan sumber pengetahuan di abad 21 ini adalah berkaitan dengan teknologi dan maklumat (ICT). Namun demikian, jumlah responden yang menjawab pengetahuan dan kemahiran guru dalam bidang STEM masih di peringkat rendah dengan nilai min 2.55. Walaupun guru menyedari manfaat pembelajaran abad ke -21 , namun guru berhadapan dengan cabaran dalam pengajaran kerana sumber yang terhad, kelas yang padat dengan bilangan murid yang ramai di dalam satu kelas dan juga infrastruktur yang kurang menyokong pembelajaran. Dapatan ini menyokong Hamidah (2002) dan Raja Maznah (2008) menyatakan bahawa kesediaan guru melibatkan aspek fizikal, mental dan spiritual dalam pelaksanaan pengajaran abad ke -21 (PAK 21) di sekolah.

Berdasarkan kajian ini juga, didapati bahawa guru-guru pendidikan khas mahir menggalakkan murid berkomunikasi semasa melaksanakan kerja berkumpulan, Ini selaras dengan Umi Kalthom dan Ahmad (2014) menyatakan menilai keberkesanan kaedah pengajaran pembelajaran koperatif dan teori Pembelajaran Koperatif oleh Vygotsky. Melalui pembelajaran secara berkumpulan, semua murid dalam 
sesebuah kumpulan akan bekerjasama untuk menyiapkan tugasan berkumpulan dengan menggalakkan percambahan idea dan interaksi sosial dalam kumpulan. Melalui aktiviti ini juga, murid akan membina keyakinan dalam diri mereka kerana penerimaan diri dalam kumpulan kecil.

\section{Kesimpulan}

Dalam kajian yang dilaksanakan memberi gambaran bahawa tahap pelaksanaan pengajaran dan pembelajaran abad ke-21 ( PAK 21) di sekolah menengah program integrasi daerah Johor Bahru adalah di tahap sederhana. Dapatan purata min bagi tahap kesediaan guru daripada aspek pengetahuan adalah 2.92 dan purata min bagi tahap kesediaan min dari aspek kemahiran adalah 3.02. Perkara ini menunjukkan bahawa tahap pelaksanaan amalan PAK 21 di sekolah masih kurang walaupun mereka mempunyai pengetahuan dan kemahiran tentang PAK 21. Guru perlu dilengkapkan dengan kemahiran strategi dan kemahiran terkini sesuai dengan keperluan masa kini dengan dilengkapi resos yang baik dan kemudahan teknologi ICT yang mencukupi. Kursus pembangunan profesional di kalangan guru perlulah mencakupi kandungan pengajaran PAK 21 yang menyokong Pelan Pembangunan Malaysia 2013-2025 (KPM 2013) yang merupakan perancangan jangka masa panjang bagi pembangunan bersepadu terutama dalam pelaksanaan PAK 21 di sekolah.

Kajian lanjutan perlu dilaksanakan di peringkat IPG dan universiti awam bagi graduan dalam pendidikan. Ini perlu untuk melahirkan guru yang dilengkapi dengan padagogi abad ke-21 bagi memantapkankan lagi pengetahuan dan kemahiran dalam pelaksanaan pengajaran abad ke-21 (PAK 21) di dalam kelas. Selain itu kolaborasi pihak sekolah, PPD dan Jabatan Pendidikan Negeri (JPN) dalam mengatasi kekangan yang dihadapi oleh guru dalam pelaksanaan pengajaran abad ke-21 (PAK 21). Kesimpulannya, dapatan kajian ini akan membantu guru-guru pendidikan khas dalam menilaidan melengkapkan diridengan persediaan pengajaranagar dapat menghadapi perubahan teknologi bagi memenuhi keperluan murid berkeperluan khas ini.

\section{Rujukan}

Abd Rahman Habibi. (2014). Kesediaan Pengetahuan, Kemahiran dan Sikap Guru Pendidikan Khas Mengajar Pertanian. Universiti Kebangsaan Malaysia.

Faridah Nazir, Faiziah Samsudin, \& Amran Bakar. (2016).Pengajaran dan Pembelajaran Abad Ke21( 1 st ed.). Selangor: Sasbadi Sdn Bhd

Izlin Zuraini Ishak. (2002). Kualiti Pensyarah Politeknik Lepasan Sarjana Pendidikan Kolej Universiti Tun Hussein Onn (KUITTHO). Kolej Universiti Tun Hussein Onn.

K.A. Razhiyah. (2008). Menjadi guru pendidikan khas. PTS Professional Publishing Sdn. Bhd. Kuala Lumpur

Kementerian Pendidikan Malaysia.(2013). Pelan Pembangunan Pendidikan Malaysia 2013-2025: Putrajaya.

Marry Yap, K.C. (2015). Guru berperanan lahir pelajar capai standard global. Berita Harian. https://www.bharian.com.my ( 11 Julai 2021)

Masyuniza, Y. \& Zamri, M. (2013). Penyepaduan kemahiran abad ke-21 dalam pengajaran dan pembelajaran bahasa Melayu. Prosiding Seminar Pascasiswazah Pendidikan Bahasa Melayu \& Kesusasteraan Melayu Kali Pertama, 338-352.

Mohd Mahzan, Awang, Abdul Razaq,Ahmad dan Nursyazwani, Abd Talib. (2016). Penggunnan Multimedia dalam Pendidikan Sejarah pada Abad ke-21 dan Hubungannya dengan Minat Belajar Sejarah. Jurnal Pemikir Malaysia, 7, 44-56

Nurzarina Amran \& Roslinda Rosli.(2016). Kefahaman Guru tentang Kemahiran Abad ke-2. Persidangan Antarabangsa Sains Sosial dan Kemanusiaan 11, 118-130.

Rusdin, N. M. (2018). Teachers' Readiness in Implementing $21^{\text {st }}$ Century Learning. International Journal of Academic Research in Business and Social Sciences, 8(4), 1293-1306 
DOI: https://doi.org/10.47405/mjssh.v7i1.1252

Umi Kalthom, Mahbib dan Ahmad, Esa. (2014). Kaedah Koperatif Sebagai Pilihan Kelas Abad 21: Sorotan Literatur. International Seminar on Technical and Vocational Education 2014 (TVEIS 2014). http://eprints.uthm.edu.my/ (11 Julai 2021)

Zamri Mahamod, Masyunizah Yunos \& Yahya Othman. (2014). Sikap dan Persepsi Murid terhadap Mata Pelajaran Bahasa Melayu dengan Kemahiran Abad ke-21. Seminar Kebangsaan Majlis Dekan-Dekan Pendidikan IPTA 22: ( MDP-42). Bangi: Fakulti Pendidikan UKM 